\title{
Corpus
}

Archivos virtuales de la alteridad americana

Vol. 11, No. 1 | 2021

Enero / Junio de 2021

\section{Discursos de aboriginalidad entre los lule-vilela del MOCASE. Tensiones entre la demanda estatal de etnicidad y apertura indigenista de las identidades criollas}

Discourses of Aboriginality among the Lule-Vilelas of the MOCASE. Tensions between the state demand of ethnicity and the indigenous openness of Creole identities

\section{Pablo Concha Merlo}

\section{(2) OpenEdition}

Journals

Electronic version

URL: https://journals.openedition.org/corpusarchivos/4600

DOI: 10.4000/corpusarchivos.4600

ISSN: 1853-8037

\section{Publisher}

Diego Escolar

\section{Electronic reference}

Pablo Concha Merlo, «Discursos de aboriginalidad entre los lule-vilela del MOCASE. Tensiones entre la demanda estatal de etnicidad y apertura indigenista de las identidades criollas», Corpus [En línea], Vol. 11, No. 1 | 2021, Publicado el 29 junio 2021, consultado el 03 julio 2021. URL: http:// journals.openedition.org/corpusarchivos/4600 ; DOI: https://doi.org/10.4000/corpusarchivos.4600

This text was automatically generated on 3 July 2021. 


\section{Discursos de aboriginalidad entre los lule-vilela del MOCASE.} Tensiones entre la demanda estatal de etnicidad y apertura indigenista de las identidades criollas

Discourses of Aboriginality among the Lule-Vilelas of the MOCASE. Tensions between the state demand of ethnicity and the indigenous openness of Creole identities

Pablo Concha Merlo

\section{EDITOR'S NOTE}

Fecha de recepción del original: 31/10/2020

Fecha de aceptación para publicación: 07/06/2021

\section{Introducción}

El presente artículo etnográfico analiza las características asumidas por discursos de aboriginalidad (Briones, 2004) entre miembros del MOCASE-VC adscriptos a la identidad étnica lule-vilela en los últimos quince años, en los departamentos Copo y Alberdi de la provincia argentina de Santiago del Estero. El objetivo consiste en rastrear, describir y analizar significantes movilizados en la presentación (Goffman, 2019) en diferentes contextos de la vida cotidiana en calidad de miembros de dicha etnia indígena. No obstante, el texto pone a consideración la construcción de actividad discursiva identitaria como una producción mediada por fuerzas culturales y sociales 
que trascienden espacio-temporalmente las relaciones de co-presencia estructurantes de las situaciones concretas y exigen un tipo de análisis multi-escalar e histórico. En otras palabras, considero las practicas identitarias como mediadas por procesos de hegemonía/resistencia significativos en la constitución de la subjetividad de mis interlocutores.

2 A fin de poder caracterizar estas fuerzas en tensión, apropiadas por las agencias discursivas de quienes se presentan en la vida cotidiana remarcando diacríticos de aboriginalidad, es necesario remitirnos a ciertos debates teóricos ineludibles de las últimas décadas. Por un lado, a una literatura prolífica de intelectuales de diversas disciplinas sociales y humanísticas, quienes señalaron la activa producción de diversidad identitaria como efecto de procesos geopolíticos a escala global (Friedman, 2001; Abélés, 2012; Augé, 2014). Dentro de estas líneas, es conveniente situarnos en enfoques específicamente antropológicos y latinoamericanos en el marco de los cuales se mostró cómo un nuevo orden transnacional contemporáneo fue incentivando la afirmación de diferencias étnicas y culturales en una rúbrica fuertemente atravesada por lo jurídico. Este proceso fue caracterizado por Briones $(2004,2005)$ en términos de juridizalización del derecho indígena a la diferencia cultural. Y, según Segato (1998), la diseminación de esta ola identitaria, estructurada en base a la demanda de derechos, fue de la mano con un proceso de incorporación, por parte de los Estados periféricos del orden mundial, de dispositivos legales inspirados en modelos de gestión de la diversidad dominantes en centros imperiales como los EEUU.

$\mathrm{Si}$, por un lado, estas perspectivas centradas en procesos geopolíticos a escala global tuvieron un rol decisivo en contrarrestar enfoques que Brubaker y Cooper (2001) conceptualizaron en términos de "constructivismos cliché", también se hizo evidente un acento denodado en lo global, olvidando la trama constitutiva de los Estados-nación y los procesos hegemónicos de los cuales estas formaciones político-territoriales son corolarios. En este sentido, tales líneas de análisis pusieron de relieve cómo cierta vulgata constructivista se había inmiscuido otorgando a los agentes la capacidad de manipular a piacere sus identidades en situaciones de la vida cotidiana, desatendiendo la complejidad de procesos estructurantes capaces de multiplicar y regular la dirección de las redefiniciones identitarias a escala global. Pero olvidaron cómo las dinámicas desatadas a escala mundial estaban mediadas y entraban en tensión con tramas de estatalidad con una activa capacidad para producir sujetos mediante la elaboración de narrativas identitarias nacionales y sub-nacionales (Briones, 2004).

En el marco de esta crítica a las perspectivas transnacionales, Segato (1998) y Briones (2004, 2005) fueron forjando el concepto de formaciones nacionales/provinciales de alteridad. Discursos hegemónicos constitutivos de territorios políticamente definidos, capaces de regular las identidades en tanto descansan en complejas articulaciones entre sistemas económicos sociales, instituciones jurídico-políticas, aparatos ideológicos y formas particulares de resistencia. El concepto da cuenta de lógicas a partir de las cuales narrativas identitarias nacionales/provinciales se afirman excluyendo o alterizando a grupos en base a marcaciones selectivamente racializadas y etnicizadas desde lugares de poder (Briones, 2005, p. 15). Estas formaciones implican, no solo alterizaciones de determinados segmentos considerados seres abyectos (Butler, 2015), sino también la imposición de cierto modelo de sujeto/ciudadano como norma invisible, y la consecuente jerarquización tácita de segmentos incluidos en función de proximidades y lejanías. 
5 Si bien en el mundo contemporáneo global se pudo observar la intensificación de la diversidad como modalidad en virtud de la cual grupos subalternos demandan derechos y negocian políticamente con los Estados, también las formaciones nacionales/ provinciales de alteridad (Briones, 2005) mantienen un activo poder de interpelación. En este sentido, el mundo contemporáneo muestra cómo ambas fuerzas se encuentran en una tensión paradojal ya constitutiva de la realidad en la que estamos insertos (Auge, 2014). No solamente al interior de las instituciones estatales encargadas de gestionar las diferencias, sino también en las subjetividades producidas $-\mathrm{y}$ negociadas - en parte con actos de estatalidad bicéfalos, a lo largo de procesos que escenifican al Estado mediante visajes múltiples e incluso contradictorios (Blázquez, 2014).

6 Se trata de una experiencia histórica cuya huella es susceptible de ser encontrada en los relatos identitarios de quienes adscribieron en las últimas décadas a etnias indígenas "re-emergentes, es decir, en los imaginarios históricos de sujetos pertenecientes a pueblos a los que los dispositivos hegemónicos nacionales/provinciales declararon extintos y que, en el presente, se organizan y participan en la arena publica como miembros de colectivos indígenas" (Rodríguez, 2017, p. 1), a partir de ciertas agencias políticas que no dejan de estar vinculadas a un nuevo orden jurídico e ideológico imperante a nivel global, en el marco del cual se posibilitan y legitiman las demandas por la diferencia. Así, comprender y explicar los imaginarios implica poder complejizar su surgimiento a partir de múltiples relaciones de poder que los incitan, los estabilizan o los desestabilizan, los matizan o los censuran, a lo largo de experiencias históricas específicas.

7 En el caso puntual que trabajamos en este artículo, uno de los acontecimientos más significativos en el contexto del involucramiento político (Quiroz, 2011) con el MOCASEVC fue que un gran número de los actores que pasaron a formar parte del movimiento en el extremo norte del Chaco santiagueño durante las últimas décadas, ${ }^{1}$ en los departamentos Copo y Alberdi, demandaron al Estado ser reconocidos legalmente como integrantes de la etnia lule-vilela en el contexto de un marco jurídico-identitario que posibilitaba la realización de estas acciones políticas.

8 Estos procesos de auto-adscripción y el posterior reconocimiento legal por parte del Estado implicaron la reemergencia (Rodríguez, 2017) en la escena pública de etnias consideradas extintas desde la colonia por los imaginarios históricos hegemónicos nacionales/provinciales (Escolar, 2007; Martínez, Taboada, Auat, 2011; Rodríguez, 2017; Lazzari, 2017), y que dichas identidades fueran adoptadas por poblaciones que durante el siglo XX fueron inteligidas/producidas como "criollas" (Grosso, 2008) en el marco de esta misma formación nacional/provincial de alteridad (Briones, 2005). Esto último significó la resegmentación del espacio identitario unificado del que los sujetos formaban parte hasta una década atrás (Friedman, 2001), en virtud de un largo y sostenido proceso de nacionalización/provincialización de las subjetividades mediante diferentes prácticas de estatalidad operadas sobre las identidades (Corrigan y Sayer, 2007) a fin de tornar invisibles las heterogeneidades constitutivas del espacio social.

9 La dinámica descripta hace que nos encontremos con una situación paradojal al interior del espacio identitario local chaco-santiagueño, entre lo que un régimen de identidad/alteridad nacional/provincial posibilita, como parte de una formación hegemónica residual (Williams, 1997) que dio estabilidad a las identidades rurales durante el siglo XX, y lo que un nuevo régimen estatal-global emergente (Williams, 1997) permite ser a ciertos actores organizados en torno a movimientos sociales e 
identidades étnicas reemergentes (Rodríguez, 2017). Esto último, en virtud de que "criollo" resultaba una identidad afirmada históricamente en antagonismo con el "indio chaqueño" (o con el imaginario hegemónico), y, por dicho motivo, impedía a sus portadores, hasta algún tiempo atrás, adscribirse en algún grupo étnico alterizado por el discurso nacional.

El argumento sostenido en el texto plantea que en las construcciones discursivas de quienes adscriben a identidades indígenas en el marco de este espacio identitario fragmentado, se puede encontrar una oscilación productiva entre dos formas asumida por dicha identidad. Por un lado, es posible observar el predominio de una adscripción más marcadamente étnico-política (Segato, 1998) operativa en contextos de demanda política y jurídica a instituciones estatales, situaciones en las que actores investidos de estatalidad aparecían en escenas o en algunos escenarios percibidos como arena de disputa con actores externos al movimiento. Por otro, es posible observar un indigenismo de "entrecasa"; una forma alternativa de política de la alteridad (Segato, 1998) cuya circulación discursiva se daba al interior de las redes movilizadas por la organización de base, que se prestaban como contextos propicios para prácticas de reflexividad en las cuales se resignifican activamente discursos hegemónicos y sus significantes. Al final del texto se retoman los diacríticos mediante los cuales se construye aboriginalidad en tiempo presente y dan pie a pensar formas no necesariamente étnicas como un nuevo horizonte político.

\section{Metodología}

11 La investigación es resultado de un proceso de investigación a partir de la cual obtuve mi tesis doctoral en 2019, en un trabajo realizado desde un enfoque etnográfico histórico (Rockwell, 2009). De este modo, los datos y las interpretaciones plasmadas en la descripciones y argumentos esgrimidos provienen de dos tipos de fuentes. En primer lugar, la tesis fue resultado de la realización de trabajo de campo entre 2014 y 2019 en distintas comunidades ubicadas al oeste los departamentos Alberdi y Copo. En segundo, a partir de un trabajo de archivo significativo a través del cual pude recopilar información considerablemente importante para la investigación.

El trabajo de campo etnográfico fue realizado a partir de múltiples estadías que totalizan sesenta y ocho días conviviendo con diferentes familias tanto en parajes rurales como en la cabecera de los departamentos Copo y Alberdi. A partir de esta inserción en el territorio, pude intercambiar puntos de vista sobre los procesos de reemergencia (Rodríguez, 2017) con 72 individuos que forman parte del MOCASE-VC, de los cuales 63 se reconocían lule-vilela, y con 25 individuos que no pertenecían al movimiento. En su gran mayoría se trató de diálogos desarrollados en el marco de una estrategia de abordaje basada en observación participante durante actividades desarrolladas por los miembros del movimiento y, en 14 casos puntuales, de entrevistas semi-estructuradas en profundidad (Achilli, 2005; Pizzarro, 2006).

El trabajo de archivo, por su parte, tuvo como objetivo la elaboración de un corpus en base a fuentes escritas cuyo marco de referencia fuera el Chaco santiagueño. Esto implicó la formación de un archivo sumamente heterogéneo en lo que respecta al formato de los textos: censos y estadísticas oficiales, memorias descriptivas producidas por agentes estatales, descripciones realizadas por viajeros, agrimensores, naturalistas del siglo XIX, piezas de literatura y periódicos. El corpus también incluye textos 
producidos por autores nacidos y criados en el Chaco santiagueño entre principios de siglo XX y las primeras décadas del siglo XXI, la mayoría de los cuales se desempeñaron en actividades vinculadas al sistema educativo. $\mathrm{Y}$, por último, materiales producidos por el MOCASE-VC en los últimos veinte años.

Algunas notas sobre los regímenes identitarios nacionales/provinciales y su recepción en el Chaco santiagueño

La principal actividad de estos pueblos era la explotación forestal, por lo que empresarios madereros venidos de afuera instalan aserraderos y hornos de carbón. Los naturales del lugar, de la noche para la mañana se encuentran convertidos en peones de los turcos (sirio-libaneses). Este copeño sometido al patrón turco, es el prototipo zonal del criollo argentino que quedó sometido al extranjero que llegó con aires de autosuficiencia arrollando, atropellando y esclavizando al criollo surgido durante la colonización española (siempre con apoyo irrestricto de los gobiernos) (...) al encontrarse este hombre con el extranjero triunfante, se auto margina y se siente frustrado, y esto lo ha marcado con tal complejo de inferioridad (Mansilla, 2013, p. 8). ${ }^{2}$

Había indios. Pero claro, con el tiempo los indios, algunos se civilizaron porque no eran tan salvajes, digamos así (...) yo conocí un hombre que había sido el primer poblador que ha venido ahí. Y cuando él vino, dice que estaban los indios todavía. Pero claro, él no sé cómo hizo para poder entrevistarse con ellos, para que no lo maten a él (2012 Grupo de Memoria Histórica MOCASE-VC, p. 19).

15 En el caso argentino, la afirmación estatal de la identidad nacional desde fines del XIX supuso no solo la alterización de la aboriginalidad, sino también la imposición de un modelo de ciudadano argentino blanco y europeo como canon que encubría otros linajes posibles (Briones, 2005; Segato, 2010). En el proceso de alcanzar la norma ciudadana soñada por las élites, era posible encontrar un amplio y heterogéneo gradiente compuesto por segmentos sociales de diversos orígenes y trayectorias dispares. En el escalafón más bajo de este declive se encontraba el "criollo", quien por definición no era extranjero sino habitante no-blanco de la extensísima y heterogénea campaña argentina.

Como fue trabajado por diferentes autores en las últimas décadas (Adamovsky, 2014; Prieto, 2006, Chamosa, 2012), la figura del "criollo" emergió como un perfil de la literatura gauchesca pampeana del siglo XIX, pero en las décadas subsiguientes se convirtió en una categoría usada para clasificar a vastos sectores populares rurales de distintos lugares del país. A pesar de tener una connotación negativa en un principio, en tanto "criollo" servía para designar a quienes no cumplían en general con la norma oficial de una nación blanca y europea - pero no podían ser eyectados ni extranjerizados (Briones, 2005)-, ${ }^{3}$ distintos proyectos nacionalistas-culturales canonizaron su figura a lo largo de la primera mitad del siglo XX. De este modo, fue exaltado como símbolo del auténtico ser nacional.

Para ello, eligieron/instituyeron una serie de discursos que blanqueaban o mitigaban la alusión a orígenes no-blancos en el plano oficial, al mismo tiempo que lo posicionaban como emblema de un nuevo relato nacional sostenido principalmente por las élites de las provincias del "interior", organizadas en torno a la oligarquía azucarera tucumana (Chamosa, 2012). En Santiago del Estero, esta impronta tuvo un rol determinante en la producción de narrativas identitarias por parte de las élites provinciales quienes "reivindican su criollismo como título de nobleza" (Martínez y Taboada, 2011, p. 186) frente a la oleada migratoria proveniente de Europa en los primeros cuarenta años del siglo XX. Estas circunstancias, y el posterior arribo del estado de bienestar peronista, 
que supo apropiarse de este imaginario creado en el marco de un nacionalismo cultural conservador (Chamosa, 2012; Adamovsky, 2014), hicieron que los sectores populares terminaran apropiando la categoría como identidad social y enmarcaran su experiencia en ciertas lógicas retóricas (Adamovsky, 2015) de la literatura gauchesca.

A lo largo de mi trabajo de campo en el Chaco santiagueño, pude advertir la existencia de narrativas criollas como modo auto-presentación en la vida cotidiana -y expuestas, también, en materiales bibliográficos producidos por escritores de la región-, las cuales se intensificaban entre las personas mayores, mientras se tornaba más difusa entre los adultos jóvenes y adolescentes, sin dejar de estar presentes como una forma en la cual se estructuran los discursos identitarios. En parte, estas formas de presentarse en la vida cotidiana (Goffman, 2019) pueden ser pensadas como efectos de la imposición e introyección de lo que Briones (2005) y Segato (1998) denominan formaciones nacionales/provinciales de alteridad, en el marco de las cuales los segmentos no-blancos de la región adquirieron una posición de sujeto (Hall, 1992) legítima.

Con esta posición de sujeto legítima, también se dotó a los nativos de múltiples espacios rurales de marcos interpretativos basados en lógicas retoricas homogéneas inspiradas en la literatura, las cuales operaron como guiones en las tramas vitales posibilitando la inserción en la comunidad nacional. Sin embargo, la apropiación de la identidad criolla como significante aglutinador se articuló también en base a experiencias históricas (Briones, 1994; Gordillo, 2010) regionales y localizadas, en el marco de las cuales se estructuraron diferencias y desigualdades específicas, es decir, a partir de relaciones localmente vividas que dieron una impronta particular a las construcciones identitarias.

Un primer elemento a tener en cuenta es que, como advirtió Grosso (2008) para el caso santiagueño, la retórica criolla admite al menos dos visajes según quiénes sean los que la enuncian y el contexto. Por un lado, una interpretación hispanista de lo que significa ser "criollo", en donde las referencias a antepasados remotos provenientes de España, durante la Colonia, obturan la posibilidad de linajes indígenas. Por otro, una perspectiva en la cual campesinos se reconocen provenientes de un proceso de mestizaje entre "españoles" e "indios" (tan solo 10 personas de las entrevistadas dijeron ser descendientes de españoles y negaron ascendencias indígenas).

21 Si bien ambas interpretaciones conviven en la ambigüedad del discurso local y permiten aglutinar bajo un mismo significante a sujetos con trayectorias heterogéneas, suele ser frecuente el predominio de la primera entre quienes son o descienden de "principales" de la campaña, ${ }^{4}$ mientras la versión mestiza domina entre sectores más postergados en términos de estatus socioeconómico (Grosso, 2008). No obstante, hasta fechas no muy lejanas, era común la elección -o invención- del linaje español como elemento determinante entre los segundos, dado el predominio de un imaginario en el que una gota de sangre europea era suficiente para inscribirlos en linajes hispánicos. ${ }^{5}$

En diálogo con personas de la zona, sin embargo, la ascendencia hispánica adquiría rasgos conjeturales dado que no podían establecer con certeza quiénes eran, cuándo arribaron y de dónde venían los presuntos antepasados "españoles", evidenciando el efecto ideológico de un discurso criollista hegemónico a partir del cual las personas de la región se imaginaban como el corolario de conquistas o de procesos de mestizaje entre españoles e indígenas:

Carolina2021-06-21T13:19:00CAAPocho (58): - ¿Usted, de que raza es su familia? 
Investigador: -Portugueses, italianos y turcos, también, pero soy malo para los negocios (risas).

Mariano (23): - ¿Nosotros de quién descendemos, Pocho? ¿De los indios?

Pocho: -No, algo de español debemos tener también (...)

(Conversación con Pocho y Mariano, del paraje “Lote A-B", 1/8/2015) 
desarrolladas hasta la intervención militar conducida por el entonces ministro de guerra Benjamín Victorica en 1885, durante la primera presidencia de Roca (Lenton, 2005). En efecto, los escenarios fronterizos se encuentran todavía presentes a través de memorias difusas y fragmentarias transmitidas por antepasados, mixturadas comúnmente con elementos de un imaginario hegemónico en el cual el "indio" aparece evocado como un animal salvaje e indómito, poco apto para el trabajo, anómico, brutal y falto de higiene. Como es de común conocimiento, esta visión respecto a los grupos étnicos chaqueños fue construida por las élites nacionales y provinciales desde el siglo XIX, en el contexto de procesos de expansión militarizada de las fronteras internas denominadas desiertos (Lenton, 2005). ${ }^{8}$

Caso paradigmático a escala provincial es el de Alejandro Gancedo en sus Memorias descriptivas de Santiago del Estero (1885), quien subsumía a colectivos étnicos bajo la categoría "animales bimanos", al mismo tiempo que los desalojaba del territorio santiagueño y de la posibilidad de la identidad provincial, afirmado su inequívoca procedencia chaqueña (Bonetti, 2016; Concha Merlo, 2019). Aun cuando los límites territoriales/identitarios en este mundo todavía fronterizo eran inciertos, la imposición de este imaginario significó la instalación de un régimen de diferenciación tajante y antagónico entre las poblaciones "paisanas"/"gauchas" de Santiago -después representadas como "criollos"- y los "indios del Chaco", identificados como enemigos tenaces de los intereses estatales de soberanía nacional y provincial sobre los “desiertos" (Lenton, 2005; Concha Merlo, 2019).

Dicho régimen identitario, según el cual no resultaba plausible ser santiagueño y miembro de una etnia indígena al mismo tiempo, se replicó posteriormente en una obra de la literatura de enorme importancia en la construcción identitaria provincial de la primera década del siglo XX, como fue El país de la Selva (Rojas, 1907). La pieza literaria de Rojas narra un escenario post-fronterizo, en el cual poblaciones campesinas consideradas santiagueñas eran descriptas como la síntesis sui generis de dos grandes civilizaciones, como la española y la incaica, y los rasgos percibidos como propiamente indígenas eran tipificados como subsistencias folclóricas prontas a desaparecer con el avance de la civilización en los montes santiagueños. Como contraste del campesino santiagueño de la frontera, emergía el indio salvaje proveniente del Chaco, que, ya derrotado por el Ejército nacional, aparecía vencido moralmente y subordinado como fuerza de trabajo de estancias y obrajes, a pesar de ser expulsado simbólicamente del imaginario identitario provincial como sujeto posible (Rojas, 1907; Gallo Schaefer, 1911; González Trilla, 1921).

Este régimen de diferenciación dicotómico contribuyó al soterramiento de matices e intensidades característicos de los emplazamientos fronterizos del siglo XIX, como lo era la región actualmente habitada por grupos lule-vilela (Farberman, 2019). Y, de este modo, se fue instalando desde fines del siglo XIX un relato provincial hegemónico por el cual se declaraba a Santiago del Estero libre de grupos étnicos y se consideraba como "chaqueños" a los grupos aborígenes que habitaban dentro de los límites políticos de la provincia. En oposición a esta perspectiva, algunas personas de la zona señalaban que:

Pablo2021-06-08T10:13:00PVicente Cuellar: -Lo que poco me acuerdo, porque había sido un chico, es de los indios que habían sabido tener la carpa aquí, como a dos kilómetros. Eso me acuerdo. Porque aquí, ahí de la central para acá, había otra carpa, también (...). Y allá, por Boquerón (...).

Entrevistador: - ¿Pero y los matacos que conoció los conoció por aquí o para el Chaco? (...) 
Vicente Cuellar: -Aquí nomás. Aquí. Era la fuerza de los matacos. Y debía ser, porque hay muchos vestidos, todavía. (MOCASE-VC, 2016)

Ahora bien, la asimilación de esta perspectiva hegemónica nacional/provincial del "indio" como ser infrahumano o en estado de animalidad y exterior a la identidad provincial pasó a conformar un elemento crucial en la formación del imaginario criollo, que los actores del Chaco santiagueño construyeron a lo largo del siglo XX a partir de un trabajo de inculcación operado por las escuelas rurales (Moreno Saravia, 1938; López, 1950 [1938]). ${ }^{9}$ El "indio" devino, en este régimen localizado, el otro abyecto (Butler, 2015), un espectro amenazante que fungía en la subjetividad local como exterior constitutivo (Butler, 2015). En otras palabras, una identidad denegada que operaba al interior de la formación discursiva como espejo negativo e imperativo de diferenciación, en la medida en que condensaba la totalidad de atributos de los cuales es necesario desligarse a fin de consolidar la posición de sujeto "criollo" (Moreno Saravia, 1938). Un imaginario que incluso se volvió parte de las identidades de quienes admitían tener antepasados indígenas.

Este elemento constitutivo pero exterior al discurso criollo se hizo evidente en el hecho de que, algunos interlocutores (22 individuos) con los cuales interactué durante mi trabajo de campo, ante la sugerencia de reconocimientos étnicos o al sentirse sospechados de formar parte de alguna de ellas, invocaban la identidad criolla o el hecho de ser mestizos como una credencial que valdría para no ser confundidos, como si esto significara lisa y llanamente no-indio. Esta visión del indio como ser salvaje sucedía con fuerte intensidad entre quienes no formaban parte de organizaciones sociales como el MOCASE-VC, y, por tanto, no habían atravesado experiencias de ruptura respecto a concepciones dominantes de lo indígena, pudiendo sentirse visceralmente agraviados al ser confundidos con esos seres que imaginaban brutales y salvajes, desnudos, sucios, etc. Además, demostraban rechazo tanto a la posibilidad de reconocimiento étnico como a sus familiares o amigos reconocidos. Por otra parte, esta impronta no dejaba de estar presente de modo muy matizado entre los sujetos autorreconocidos como lule-vilela dentro del MOCASE-VC, entre quienes aparecía la representación de que al menos algunos de sus antepasados "originarios" o "indios" eran "baguales" (12 individuos) o "incivilizados" (14 individuos) o "bárbaros" (7 individuos): ${ }^{10}$

Silvina (Casa)2021-06-15T20:29:00CNicasio: -No era algo que íbamos a andar diciendo, pero esas cosas se sabían en la casa, de chico le decían. Mi papá sabía decir que somos de los originarios, de los indios vamos a decir. Tenemos la sangre (...).

Entrevistador: - ¿Cómo era la vida de los originarios aquí? ¿Cómo vivían, era muy distinta a la vida que han tenido después?

Nicasio: -Claro, muy distinta ya, andaban vestidos, no era gente que buscaba problemas, así era, como yo le digo ¿Por qué habrá sido gente tan baguala? ¿No? (Entrevista con don Nicasio, Runa Pozo, septiembre de 2015. El destacado es del autor).

33 Ahora bien, a pesar de haberse impuesto con mucho vigor, desde su formación este régimen identitario mantuvo fallas evidentes a la hora de trazar fronteras rígidas entre criollos fronterizos e indios chaqueños, en virtud de la existencia de interfaces de paridad entre segmentos que poseían un marcado fenotipo percibido como "indio" y desplegaban prácticas culturales percibidas como indígenas, tales como, por ejemplo, estrategias de subsistencia basadas en la caza/recolección en espacios montaraces: ${ }^{11}$

Es muy curiosa la vida de los obrajeros en el monte. Viven en pequeñas chozas,

fabricadas con sunchos y latas de kerosene, en notable promiscuidad. La mayoría es 
gente indígena. Estos aborígenes constituyen la base de la mano de obra en las explotaciones forestales. Hablan la quichua, su lengua nativa (...) Si las necesidades de esta raza fueran mayores o más difíciles de practicar, habría ya desaparecido (...) pero escapan de esa suerte tanto porque su comida la constituye el maíz (...) y cuando escasea el maíz, los montes brindan diferentes frutos y miel silvestre; huevos de aves del campo; y la tierra, por doquier, animales diversos. Esta raza, en humilde concepto del autor, pertenecerá a la historia (...) asfixiada por la aglomeración de otras razas superiores que se arrebataran su dominio, cumpliéndose las leyes darwinianas de la lucha por la existencia y de la selección natural (...). Sin embargo, es obra del buen gobierno conservar y proteger esa raza que ya muere. Solo ella está hecha para las grandes fatigas en nuestro suelo (Gallo Schaefer, 1911, pp. 32-33).

Si resulta importante la visión de un intelectual santiagueño como Gallo Schaefer (1911), es porque la explicitación de su percepción evolucionista y racializada diverge notablemente respecto al sistema de clasificación movilizado por trabajos intelectuales consagrados como El país de la selva (Rojas, 1907). Si Rojas devuelve una imagen idealizada de los campesinos de la frontera al describirlos como producto de una síntesis sui generis entre altas civilizaciones como la española y la incaica (Farberman, 2010), Gallo Schaefer expresa una mirada más cruda y llamativamente concordante con el régimen de trabajo impuesto forzadamente en el contexto de la expansión del capital obrajero en estos espacios fronterizos (Gancedo, 1885; Abregú Virreyra, 1917; Huret, 1987; Bialé Masse, 2010) recientemente colonizados del Chaco austral.

Esa "gente indígena", lejos de ser reservorio de tradiciones auténticamente santiagueñas, como sostenía Ricardo Rojas (1907) en su discurso culturalista, conformaban una forma de alteridad fuertemente denostada por las élites locales, quienes encontraban como único punto de valoración la posibilidad de sometimiento a formas cruentas de explotación laboral como las que se habían gestado durante la formación de la económica obrajera y en todo el Chaco austral luego de la denominada Conquista del desierto verde (Trinchero, 2000).

A pesar de que se ha desestimado el peso simbólico de la racialización en el sentido común hegemónico nacional y provincial bajo una pretendida ciudadanía igualitaria, lo cierto es que, en cuanto a clasificación se trata, esta noción mantuvo una fuerza legitimadora de las desigualdades gestadas en la primera mitad de siglo, con una impronta performativa que sigue teniendo un vigor significativo en las subjetividades sub-alternas (Lenton, 2005).

De hecho, durante mi intercambio con las personas en los departamentos Alberdi y Copo, el señalamiento de la marca corporal indígena como sello de origen fue un elemento que aparecía recurrentemente a pesar de que generaba incomodidad y controversias entre sus portadores, incluso entre las personas autorreconocidas lulevilela. Y algunos de ellos describieron esta característica propia manifestando el hecho de tener aspecto "paisano" (18 individuos), una categoría que operaba como eufemismo usado para aludir a rasgos fenotípicos y orígenes indígenas entre los habitantes de la región chaco santiagueña. Por el contrario, "mataco" era sinónimo de "paisano" usado de modo despectivo como forma de burla o insulto convirtiendo los orígenes de sus portadores en estigmas. Tan solo un individuo de los entrevistados (reconocido como lule-vilela), Javier Calermo, se refirió a sus abuelos como "matacos" ya "medio gauchos", mientras que un vecino mayor de la zona me dijo estar seguro de que en realidad los Calermo venían de los mocovíes. 

a Vía Campesina ${ }^{14} \mathrm{y}$, por otro, el MOCASE autoproclamado "histórico" - “institucional" desde el punto de vista de los mocaseros del Vía Campesina-. En el año 2019, estas organizaciones se unieron nuevamente bajo el nombre de MOCASE, coexistiendo e hibridándose dos formas de organización y perfiles políticos- 
territoriales que se habían diferenciado notablemente desde 2001 hasta el presente. No obstante, cuando realicé mi trabajo de campo, entre 2014 y 2018, las organizaciones se encontraban escindidas y mantenían disputas respecto a los modos de construcción del territorio.

Dentro de estas diferencias, la más notable era que el MOCASE-Vía Campesina había tendido desde sus orígenes a un perfil indigenista cada vez más marcado, que terminó de consolidarse con la sanción de la ley de emergencia territorial de 2006 (26161), mientras que en el "Histórico" o "Institucional" circulaban discursos que impugnaban fuertemente el proceso de reemergencia a pesar de que algunas comunidades habían empezado procesos de reconocimiento. Dicho giro indigenista llevó a la articulación del MOCASE-VC con el MNCI (Movimiento Nacional Campesino Indígena), introduciendo la identidad "campesino-indígena" como un horizonte que muchos "mocaseros" adoptaron como un significante aglutinador (Hall, 2003) en las disputas territoriales.

En un sentido importante, las redefiniciones étnicas generadas en el marco del MOCASE-VC pueden ser descriptas como una identidad política (Segato, 1998), dado que posibilitaron la demanda al Estado en términos de minoría y, en este caso puntual, la defensa territorial. Sin embargo, hablar de identidad política puede llevarnos a dos lecturas equivocadas. La primera de ellas, quizás más obvia, radica en percibir dichas transformaciones identitarias como movimientos instrumentales que actores racionales usarían para obtener beneficios en una nueva coyuntura histórica, sin que esas declaraciones de estado y las experiencias de organización política transformen la subjetividad de los grupos subalternos organizados en torno a movimientos sociales. La menos evidente consiste en una visión constructivista cliché (Briones, 2007) para la cual los sujetos podrían adoptar nuevas identidades, transmutando de la noche a la mañana su subjetividad histórica.

Lo cierto es que, a fin de poder comprender de modo cabal los procesos particulares de cada grupo, es necesario referirnos a dos factores de crucial importancia. El primero de ellos remite a la eficacia de los actos estatales en la producción de subjetividad (Corringam y Sayer, 2007), en lo que respecta al reconocimiento de los grupos étnicos. Mientras que un segundo elemento se relaciona a las experiencias históricas de inclusión/alteridad y resistencia (Segato, 1998) de los colectivos reconocidos, como locus desde donde se provee de tramas significantes activamente apropiadas en la elaboración de narrativas reemergentes (Rodríguez, 2017).

47 Vistos desde el punto de vista de los efectos simbólicos producidos por actos oficiales sobre el mundo social, los procesos de reconocimiento jurídico pueden ser entendidos como prácticas de Estado cuyo corolario consiste en dotar de realidad plena y legitima (Bourdieu, 2014) a grupos étnicos emergentes, instituyendo, de este modo, el estatus de grupo preexistente respecto al Estado y la nación. Confiriéndoles, así mismo, una serie de derechos en calidad de minoría nativa históricamente violentada y habilitándolos a demandar una serie de derechos particulares. Los actos de institución estatal, en este sentido, poseen suficiente fuerza para generar efectos performáticos (Butler, 2015) intensos -no determinantes- en las subjetividades de quienes atraviesan tales procesos. Como veremos a lo largo del texto, se imponen como realidades con un gradiente diferencial en distintos contextos y sujetos.

48 Por otro lado, la posibilidad de la eficacia y recepción de dichas transformaciones se encuentra supeditada a las experiencias históricas, tanto de larga duración como reciente. Es decir, mediada, a la vez, por la experiencia acumulada por distintas 
generaciones, y la que proveen los acontecimientos recientes como, específicamente, conflictos territoriales y procesos de organización social al interior de movimientos contra hegemónicos, como es el caso del MOCASE Vía Campesina, que adhiere a formas de demanda sustentadas en el reconocimiento por la diferencia.

\section{Tensiones entre identidades políticas y experiencias históricas de alteridad}

En el caso puntual argentino, el reconocimiento legal de aboriginalidad obligaba a adoptar una identidad étnica particular y definida, mientras que, en el Chaco santiagueño, existía un amplio espectro de quienes inscribían su historia en un pasado "indio", que podríamos describir como genérico y difuso, sin memorias precisas respecto a particularidades étnicas discretas como las demandadas por la ley, a diferencia de colectivos cuya marca étnica fue constantemente visibilizada desde el siglo XIX, en virtud de ser identificados como refractarios a la soberanía nacional. o, en el caso de otras regiones como Cuyo (Escolar, 2007), donde los discursos de las élites locales contribuyeron a la unificación en torno a una sola identidad indígena, la huarpe. Como veremos a continuación, esta situación de ausencia étnica general y precisa fue suplida en un proceso de construcción que involucró una red de diferentes actores.

Tal como fue señalado por Segato (1998), la demanda estatal de diferencias específicas para el reconocimiento de derechos encuentra su origen en el hecho de que la Constitución argentina de 1994, y los avances en materia legal desarrollados en dicho país durante esta década, fueron el efecto de una incorporación al sistema jurídico de formas de gestionar la diversidad importadas/impuestas desde los EE.UU, país donde la segmentación étnico-racial era fuertemente estereotipada y taxativa, infranqueable para la mayoría de las personas asignadas oficialmente en un grupo desde su nacimiento. Algo considerablemente distinto a lo sucedido en Latinoamérica con posterioridad a los procesos independentistas, debido a las características históricas del continente del sur, donde las fronteras simbólicas se tornaron borrosas y, por tanto, sumamente porosas en lo que respecta a definiciones diacríticas en torno a líneas de color y prácticas culturales que separaban segmentos sociales (Lenton, 2005; Briones, 2005; Escolar, 2007). Estas características pueden observarse al trazar la trayectoria de la categoría "indio" con la cual grupos históricamente etiquetados como "criollos" y actualmente autorreconocidos como "lule-vilela" refieren a algunos de sus antepasados.

51 En Argentina, con el desarrollo del periodo republicano, la disolución del sistema de castas y la creación de un sistema formal de igualdad realmente impracticable, "indio" perdió el estatus jurídico (Farberman, 2019) otorgado durante la Colonia, sin por ello dejar de inscribir a grupos poblacionales en función de intereses político-territoriales de las élites. Desde el siglo XIX, la categoría fue utilizada por antonomasia para representar a grupos étnicos fronterizos refractarios a la soberanía territorial del Estado, considerados "salvajes", quienes tan solo conformaban una fracción pequeña de los heterogéneos grupos etiquetados como tales durante el periodo colonial. Sin embargo, la polisemia residual del término subsistió permitiendo marcar no oficialmente a poblaciones subalternas no-étnicas en función de rasgos fenotípicos, prácticas culturales y lugar de procedencia. 
Si "indio" se desplazó hacia los enemigos fronterizos, el término "paisano" fue adquiriendo mayor fuerza en la retórica oficial para nominar estas poblaciones no blancas y heterogéneas a lo largo del siglo XIX, muchas de las cuales conformaban la principal fuerza de trabajo y constituían ejércitos y milicias fronterizas (Rossi, 2004; Briones, 2005; Adamovsky, 2014; Farberman, 2019). "Paisano" connotaba, de esta manera, orígenes no-blancos, más precisamente la raíz indígena de "los hijos del país", como una cuestión implícita que permitía tematizar indirectamente las negadas diferencias fenotípicas, que actuaban como signos capaces de regular interacciones en el marco de un espacio social racializado (Briones, 2005; Escolar, 2007; Segato 2010), de ahí el uso que subsiste en el espacio social chaco-santiagueño. No obstante, la corrección política en el plano oficial no era siempre correspondida en el plano de los intercambios cotidianos, donde los procesos de racialización mostraban su rostro más crudo y racista mediante prácticas discursivas y no discursivas, expresadas generalmente en relaciones laborales tan cruentas como paternalistas (Lobato y James, inédito).

Desde fines del XIX, estos sujetos liminales y heterogéneos fueron adquiriendo el estatus de "criollos" en el marco de nuevos relatos que permitían su incorporación en la escena nacional, sin que el marcaje de un signo que delataba el origen dejara de estar latente en los intercambios cotidianos a pesar de ser un tema tabú en el plano oficial (Briones, 2005; Segato, 2010).

54 En este sentido, siguiendo a Segato (1998), las experiencias históricas de alteridad son ambiguas y distan de poder reducirse en su totalidad a una política de la diferencia, étnica e inequívocamente determinada, porque las líneas divisorias entre quienes pueden ser marcados o no como "indios" son difusas y ambiguas a lo largo de la historia. Y el énfasis en algunas de estas posibilidades de marcación descansa generalmente en los contextos de enunciación.

55 Esta ambigüedad se hizo presente en el marco de mi trabajo de campo entre 2014 y 2018, poniendo de relieve lo que Segato (1998) describe como dos polos de los actuales procesos identitarios, a saber, la distinción entre identidades políticas y alteridades históricas. No como una disyuntiva, sino bajo la forma de una tensión inherente de la práctica identitaria, signada por un movimiento pendular $u$ oscilatorio entre ambas formas de practicar la identidad; un desplazamiento discursivo emergente en el contexto de interacciones con personas reconocidas lule-vilela (Pankonin, 2016) durante los últimos quince años, quienes a lo largo de múltiples intercambios rotaban sus posicionamientos identitarios indígenas con relación a diferentes articulaciones entre situaciones cotidianas y campos discursivos atravesados por procesos de hegemonía/resistencia de vasta amplitud -algo que no sucedía de modo consciente sino como resultado de una práctica mediada por distintas fuerzas sociales y culturales. Uno de estos posicionamientos podía atisbarse en la circulación de la categoría étnica "lule-vilela", la cual adquiría mayor intensidad y definición en contextos en los que mis interlocutores debían presentarse ante circunstancias investidas de estatalidad, ya sea que se tratara de escenarios típicamente estatales, como las audiencias judiciales a las que frecuentemente asistían como parte de litigios territoriales, frente a las fuerzas del orden público - las cuales respondían a las élites locales y eran puestas la mayoría de las veces al servicio de los intereses empresariales en los conflictos territoriales- o simplemente ante actores percibidos como agentes estatales. Por el contrario, "lulevilela", como forma de presentarse en la vida cotidiana (Goffman, 2019), perdía 
intensidad cuando las personas reconstruían narrativamente sus identidades indígenas en conversaciones que transcurrían en el marco de vínculos de cercanía, familiaridad, o en eventos políticos organizados con los "cumpas" del movimiento.

57 En efecto, sucedió que, en las primeras interacciones, al presentarme como antropólogo, los actores reconocidos lule-vilela tendían a identificarme como un agente de Estado, basándose en el hecho de que los relevamientos ordenados por Instituto Nacional de Asuntos Indígenas para la obtención de la personería jurídica habían sido acompañados por profesionales de la antropología. Este lineamiento en los intercambios fue generando que se vieran ante la necesidad de mostrar, de subrayar insistentemente, su ser lule-vilela mediante distintos diacríticos. Y, en distintos momentos, sucedió que los recientemente reconocidos sacaran a relucir un mapa que albergaran en sus ranchos, como un documento de Estado que permitía acreditar su etnicidad. Dichas cartografías - fotocopiadas, en su mayoría-, según me dijeron mis interlocutores, fueron obtenidas en el marco de distintas interacciones con miembros del INAI, en un proceso de reconstrucción de la "memoria histórica" y de investigación sobre los orígenes de las "comunidades indígenas", en talleres propiciados por la entidad estatal y el MOCASE-VC. Al cabo de estos encuentros de reconstrucción histórica, las familias involucradas comenzaron un proceso que llevaron a muchas de ellas a obtener personería jurídica como miembros de comunidades pertenecientes a etnias particulares plasmadas en el siguiente mapa (Imagen $\mathrm{N}^{\circ} 1$ ):

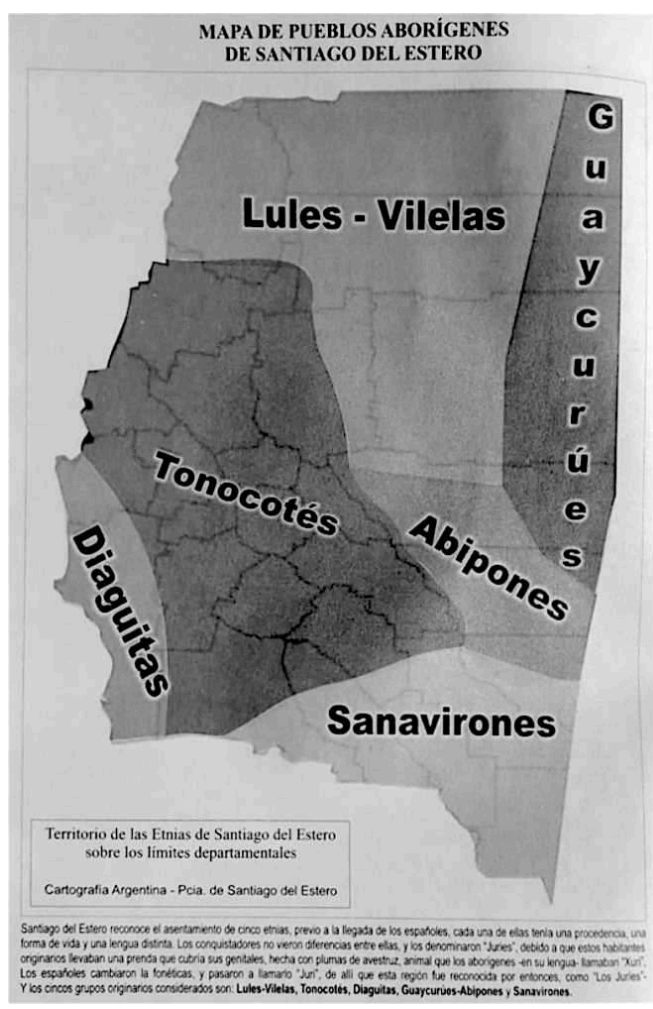

Imagen 1. Fuente: Mansilla (2013, p. 18)

Dicha imagen representa un mapa étnico-provincial de los grupos indígenas que actualmente habitan Santiago del Estero, el cual fue adquiriendo forma a partir de los procesos de reemergencia de las últimas décadas. Sin embargo resulta evidente que se encuentra inspirado en una serie de cartografías construidas por distintos intelectuales durante el siglo XX con una intención ideológica claramente opuesta, es decir, para dar 
cuenta de lo que el discurso hegemónico consideraba cuadros de la prehistoria santiagueña en alusión a grupos presuntamente extintos que habrían ocupado el actual territorio santiagueño desde el periodo prehispánico hasta el siglo XIX (Figueroa, 1924; Canals Frau, 1953; Di Lullo, 1964; Lascano, 1992; Risso Patrón, 2012).

Durante el siglo XX, esta visión hegemónica respecto a la extinción de los grupos étnicos de la provincia y particularmente del Chaco santiagueño se impuso de modo notable. En los años treinta, la protoarqueología desarrollada en la provincia contribuyó a la expulsión definitiva de los grupos chaqueños del relato identitario oficial de las élites santiagueñas. En efecto, la expansión de los obrajes madereros por el bosque chaco-santiagueño generó el descubrimiento de restos arqueológicos que atrajeron la atención de los intelectuales locales (Martínez y Taboada, 2011). Fueron los hermanos Wagner quienes se encargaron de producir conocimiento respecto a colecciones formadas rudimentariamente sin ningún tipo de metodología avalada por la comunidad científica de la época. El veredicto de estos notables difusionistas fue la invención de una presunta "Civilización chaco-santiagueña" de avanzada que habría existido con anterioridad al arribo de los grupos chaqueños considerados "salvajes" y cuya extinción habría sido obra de algún cataclismo incomprobable (Martínez y Taboada, 2011). De este modo, se desvinculaba a los grupos indígenas locales de las piezas arqueológicas encontradas en la región chaco-santiagueña.

También la antropología social tuvo un rol importante en la construcción del imaginario de una provincia sin indígenas acentuando este borramiento en la región chaco-santiagueña, donde actualmente se encuentran los grupos lule-vilela. De este modo, Santiago Bilbao señalaba en la década del sesenta que:

Parece ser que la indiada no duraba mucho tiempo reducida, y por cualquier motivo ganaba de nuevo el monte, escapando de la disciplina jesuita (...) en esta tarea de sacar indios colaboraron civiles y militares españoles, que constituyeron los troncos originarios de las familias aun existentes en la zona (Bilbao, 1964, p. 159).

61 La perspectiva de Bilbao se encontraba imbuida por la forma de criollismo hispanista descripta en apartados anteriores, a partir de la cual se negaba incluso "el mestizaje racial y cultural" (Bilbao, 1964, p. 146) y se consideraba que los indígenas fueron corridos por los españoles hacia el Chaco (Bilbao, 1964, p. 147). Dicha representación, además, se comprende también a partir de que, para los antropólogos de mediados de siglo XX, Santiago del Estero constituía un área folk por oposición a las áreas pobladas de pueblos indígenas. $\mathrm{Y}$ un dato no menor es que el texto de Bilbao era usado por el comisionado municipal de San José del Boquerón, una pequeña localidad del departamento Copo, para denegar su identidad a las familias reconocidas como indígenas y afirmar el estatus de descendientes de español entre los habitantes de dicha jurisdicción.

62 A pesar de ciertos anacronismos históricos evidentes en la cartografía étnica provincial generada a partir de los procesos de reemergencia actuales, nunca dejó de parecerme plausible para este caso puntual, dado que en la región marcada como lule-vilela se encontraba apostada una red de reducciones pobladas por grupos de las etnias lule y vilela durante la Colonia. Dicha red fronteriza, que atravesaba las actuales provincias de Salta y Santiago del Estero sobre la vera del río Salado, fue administrada primero por la Compañía de Jesús y luego por la orden franciscana, entre mediados del siglo XVIII y la Revolución independentista de 1810 (Furlong, 1939; Vitar, 1997; Farberman, 2019). Pero durante la primera mitad del siglo XIX, estos grupos reducidos a lo largo del siglo XVIII 
desaparecieron del mapa nacional y provincial (Farberman, 2019) siendo invisibilizadas sus identidades étnicas hasta los actuales procesos de reconocimiento ${ }^{15}$, restando únicamente referencias respecto a una fuerte presencia india entre los pobladores de la zona. Por ejemplo, los hermanos Mulhall $(1876$, p. 203) señalaban que los habitantes de esta región eran "indios mansos, descendido de lo que fueron convertidos en el siglo XVII por los Franciscanos", dando cuenta de la relación establecida entre las poblaciones de la región y las etnias presuntamente extintas. ${ }^{16}$

Como fue señalado más arriba, durante los procesos de reemergencia (Rodríguez, 2017) de los últimos quince años, los grupos indígenas locales fueron rearmando mediante sus luchas una cartografía étnica reconocida y legitimada por el Estado. Dicha cartografía fungió performativamente (Butler, 2016), generando que quienes se consideraban descendientes de indígenas lule, vilela, "paisanos" o simplemente "indios" inscribieran su etnicidad siguiendo los lineamientos propuestos por estos mapas étnicos a fin de completar los requisitos del sistema jurídico para obtener reconocimiento, adquiriendo esta práctica una creciente sistematicidad en la región delimitada como territorio lule-vilela. Se trató de un proceso que se llevó a cabo en toda la provincia siguiendo una dinámica similar de asignación de identidades en función de este mapa de grupos anteriormente considerados extintos por los discursos hegemónicos.

Los efectos performativos de este proceso estatal se encuentran también en el hecho de que los talleres realizados en conjunto con el INAI (Instituto Nacional de Asuntos Indígenas) les había servido para "descubrir que eran lule-vilela", como me hizo saber un anciano de la región a quien su padre le había narrado que "venían de los indios", adquiriendo de ese modo orígenes étnicos delimitados por la referencia a estas dos etnias claramente diferenciadas durante la Colonia que aparecían agrupadas en la identidad emergente de las familias reconocidas en la actualidad. Fue de este modo que esos "antiguos" antepasados, que no eran más que "indios" genéricos en muchos casos, mayormente negados, fueron dotados de identidad étnica por un acto de institución que involucró al Estado y las luchas por la restitución del pasado impulsadas por el movimiento social al cual pertenecían, comenzando a gravitar de otro modo en los imaginarios identitarios (Escolar, 2007).

Ahora bien, si en contextos signados por la presencia de los otros estatales o de disputa político-territorial la identidad lule-vilela adquiriría una intensa presencia, en contextos cotidianos alejados de marcos estatales normativos (Bourdieu, 2014) mi trabajo de campo fue abriéndose a otro rostro de la tendencia global a definirse por la diferencia indígena, donde la particularidad étnica perdía vigor dando paso a una forma de indigenismo más difusa, basada en negociaciones y resignificaciones de experiencias históricas de alteridad, que adquiría creciente aceptación entre los "mocaseros".

\section{Los "descendientes": diacríticos de una continuidad discontinua}

Etelvina del Valle Ruiz: -Con mi papá, nosotros sabíamos decir que éramos descendencia de indios ...).

Ana Cuellar: -Nosotros ya hace bastante hemos aceptado que somos indígenas.

Pero algunas personas nos decían que esa ley no existe. Que nunca se aprobó. 
Vicente Cuellar: $-Y$ bueno, ahora sabemos que de los indios era la tierra. ¿Qué no?

Esta tierra que vivimos. No era de los españoles.

Ana Cuellar: -Y sabemos de qué raza somos, y todo.

Vicente Cuellar: -Todo. Que raza somos, sabemos. (MOCASE-VC, 2016, pp. 50-51)

En contextos no estatales y en circunstancias donde la política seguía lineamientos no normativizados por procesos legales, las narrativas identitarias adquirían características no adecuadas a un marco jurídico de exigencia étnica, sino que se aproximaban a lo que Gordillo (2018) identificó como una apertura indigenista de las narrativas identitarias criollas (Pizzaro, 2006; Escolar, 2007). Con el concepto de una apertura, adquiría relieve el hecho de que, si bien en momentos anteriores se trazaba una frontera en principio infranqueable por parte de "criollos" en el mundo chacosantiagueño, en el contexto actual esta brecha simbólica era dislocada generando canales que conducían a la construcción de identificaciones colectivas, no ya -o no solo - con un segmento blanco de presuntos y conjeturales antepasados españoles, quienes aseguraban mediante su sangre no-india el estatus de "criollo", sino también con antepasados experimentados y recordados como "indios", cuya forma de aboriginalidad ya no coincidía con imaginarios abyectos de salvajismo constitutivos del criollismo formado en la primera mitad del siglo XX. Por ejemplo, Carlos Sánchez, un referente del movimiento en el departamento Alberdi que había insistido en su identidad criolla como una forma de poner distancia a las identidades lule-vilelas durante distintas entrevistas anteriores, señalaba lo siguiente:

Carlos: -Ahí (en la reducción jesuítica) reducían a su gente y la obligaban a trabajar, como esclavo dice que los tenían. Los hacían trabajar como perros.

Entrevistador: - ¿Ellos son lule-vilela también? ¿Verdad? Yo los vi y me parecía que eran "criollos", como usted.

Carlos: -Ahhh... como todos, aquí. Venimos de los indios, si somos negros. Mi hermana vive en Bs. As., me dice que ella no es ninguna india y está enojada (...) a nadie le gusta mucho, pero eso así. Mi mamá era casi india, también.

Entrevistador: - ¿Y su abuelo? ¿Él era indio también?

Carlos: -No, él era alto y blanco (...), ellos vienen aquí en la conquista a buscar tierras, del departamento Pellegrini dice que eran.

Entrevistador: $-¿$ Eso de que los reducían era en la época de la Colonia, antes de la independencia? ¿No? ¿Hace mucho tiempo?

Carlos: -Y no, después también, aquí los patrones eran gente muy viva, me acuerdo de esa pobre gente que tenían viviendo como animales aquí, trabajando por la comida, durmiendo en el piso, casi desnudos andaban, vea. (...) Antes no se sabía, se ignoraba mucho, mi abuelo tenía esa pobre gente en el puesto también, pero por lo menos algo les pagaba.

Entrevistador - ¿Eran indios? ¿Hablaban otro idioma o el mismo?

Carlos: -Sí, claro, eran indios. Algunos, pero sabían hablar algo, también. Ya era gente que se había civilizado... mi abuela también era india, era hija de indios, ella también, pero ya se habían civilizado, como le digo, ya no andaban haciendo barbaridades, eran gente trabajadora. (Entrevista en profundidad a Carlos Sánchez, Yuchán Viejo, 2016. El destacado es del autor)

67 En conversaciones posteriores, Carlos Sánchez afirmó no tener duda respecto de que su padre era indio por el hecho de que había migrado desde los bañados del rio Salado, y que esa era la "sangre" y la "raza" que ellos tenían, a pesar de que admitir su ascendencia indígena era algo que lo incomodaba profundamente.

Circular a través de las redes de sentidos ambivalentes y controversiales, en permanente reinterpretación y discusión entre mis interlocutores, debido a que los procesos de reemergencia no dejaban de ser recientes, fue mostrándome una activa 
construcción de narrativas mediante las cuales las personas se presentaban como indígenas sin alguna mediación étnica particular. En estos relatos en tensión se evidenciaba una especie de transición inconclusa entre dos regímenes identitarios hegemónicos, de los cuales uno impedía una asunción que era incentivada por el nuevo régimen y propiciada por el contexto de lucha territorial organizada en el marco de la ley 26101.

Pero la contradicción era resuelta por la mayoría de los "mocaseros" ${ }^{17}$ de un modo muy particular, señalando el hecho de ser criollos " descendencia de", "descendiente de" (15), "venir de" o "ser de" (18), y estos antepasados podían ser inscriptos como "indios", "originarios", "paisanos", "matacos", "shalacos"18, dependiendo de las circunstancias en las que se enunciaba, y las múltiples trayectorias históricas de quienes lo hacían. En general, cuando esta apertura indigenista adquiría ribetes políticos, solía ser afirmada en términos de "campesino-indígena", ${ }^{19}$ una identidad utilizada en las últimas décadas en el marco del Movimiento Nacional Campesino Indígena.

Un dato interesante es que ciertos campesinos, que se negaban rotundamente a reconocerse indígenas e impugnaban a quienes lo hacían, podían coincidir en el hecho de que algunos de sus antepasados también eran o podían ser "indios", pero al estar insertos en otras redes político-territoriales tendían a establecer discontinuidades identitarias con ellos, un patrón o práctica que pude observar entre miembros del MOCASE autodenominado "Histórico", ${ }^{20}$ dado que este movimiento tendía a rechazar los procesos de reetnización y alentaba otras estrategias de posicionamiento identitario ante conflictos territoriales. También fue notorio entre gente de los pueblos y otros parajes que mantenían cierto recelo con respecto a los movimientos sociales en general.

71 Entre los miembros autorreconocidos del MOCASE-VC, por el contrario, la representación de "venir de", o ser "descendientes de", marcaba discontinuidades y continuidades de sus ancestros inmediatos (conocidos por ellos) respecto a antepasados remotos, a quienes consideraban indígenas o indios en estado puro, quienes generalmente solían ser representados en base al imaginario abyecto de salvajismo; no obstante, también pude entrever algunos atisbos de auto-crítica en relación con esta perspectiva deshumanizante construida desde el siglo XIX.

72 Respecto a las marcas de continuidad en términos de linaje, el diacrítico con énfasis más fuertemente marcado era el que hacía referencia al hecho de estar en posesión de la raza india, la cual fungía como una prueba contundente de aboriginalidad entre mis interlocutores. Así, la "sangre", la "raza" o simplemente la referencia al fenotipo (aproximadamente 40 individuos) y, de modo en general, el cuerpo indio (Escolar, 2007; Gordillo, 2018), constituía una fuente inagotable de significantes nodales que gravitan con fuerte presencia en las prácticas identitarias. En otras palabras, algunos de sus antepasados inmediatos se encontraban en posesión de esta sangre/fenotipo y ellos también, lo cual habilitaba al reconocimiento en la perspectiva de los actores, como si se tratara de una inversión de las lógicas que habían gobernado los imaginarios criollos durante el siglo XX. De este modo, operaban como elementos articuladores en los procesos de autorreconocimiento generando una línea de conexión del criollismo hacia un indigenismo antes vedado.

73 En este sentido, resulta significativo cómo la ponderación de este diacrítico corporal tiene como trasfondo histórico lógicas de racialización aborigen (Escolar, 2007) 
inscriptas en el desarrollo histórico del espacio social chaco-santiagueño, como parte de un proceso generalizado en Argentina, pero que admite distintas intensidades en diferentes lugares. De este modo, como señala Segato (2010), el estigma de la raza al interior de una formación de características racializadas, pero negadas como forma de diferenciación, se convierte en signo susceptible de movilizar procesos identitarios en un contexto que insta a demandar por la diferencia poniendo de relieve estas experiencias de alteridad liminales y ambiguas, en lugar de generar estrategias para solaparlas. En otras palabras, deviene en emblema articulador (Hall, 1992) de una construcción identitaria reemergente capaz de reconfigurar el criollismo tendiente a negar ascendencias sub-alternizadas, conduciendo a los pobladores de la región a exhumar algunos de estos linajes negados hacia fuera del grupo familiar y convertirlos en investiduras políticas.

Creo no equivocarme al afirmar que, en torno a estas lógicas racializantes implícitas, fueron legitimadas formas de explotación cruentas tanto en los obrajes santiagueños como en otros espacios de producción capitalista importantes, como los algodonales chaqueños, en los cuales trabajaron como asalariados la mayoría de las personas mayores de cincuenta años que actualmente componen el movimiento. No es de extrañar, entonces, que las construcciones discursivas respecto a estas nuevas formas de aboriginalidad revelen la presencia de referencias a estos espacios de explotación que los criollos compartieron durante el siglo XX junto a "indios" del Chaco, donde ambos segmentos sociales eran tratados por sus patrones como "animales" - según la narración de un interlocutor-, y míseramente remunerados, en una experiencia de clase social claramente compartida en los aspectos más determinantes de dicha trayectoria:

Martín: - Y como no voy a ser indio yo, si mírame la cara. Algún día cuando vengas para mi casa te muestro a mi mama, ella es india, india. Tiene la nariz, así como los indios (...). Mi papá se ha ido hace mucho, pero él iba al Chaco para el algodón y ahí había muchos indios, siempre él decía, armaban partidos de futbol y que los indios tenían su propio equipo (...). Él sabía decir que las tolderías eran parecidas a cómo vivían aquí ellos cuando iban al obraje, armadas todas de suncho y tierra (...). Eran gente trabajadora no como dicen que son barbaros.

Entrevistador: - ¿Digamos que los indios eran parecidos a ustedes en cómo vivían y en los trabajos que hacían, y también en que eran morochos?

Martín: -Sí, nosotros somos campesinos y somos descendientes, en realidad, por eso casi todos aquí eran de la quichua. Aquí éramos todos, por más que algunos se quieran hacer los que no, todos sabemos cómo es aquí. [...] Carlos, el señor que usted visita ahora, él ha podido demostrar que es indio

Entrevistador: ¿En serio? ¿Cómo ha hecho?

Martín: -Claro, la prima de Carlos de allá, de Monte Quemado, es la que sabe bien cómo es, que iban bajando del Salado mucho antes, como en el mil ochocientos sesenta o setenta, que se encuentran con una toldería ahí y parece que eran unos indios bien malos, jentonces qué! los van a buscar y matan algunos, y en la corrida enlazan a una chica y una viejita, y las tenían ahí trabajando para ellos, y ella después tiene un hijo ahí. (Conversación con Martín Suarez, Campo Gallo, abril 2016. El destacado es del autor).

En estas narraciones aparece, por un lado, la referencia repetida al hecho de que fenotípica/racialmente no existía tanta distancia entre unos y otros. Y, de modo un poco menos intenso, también se narran episodios de interacción en los algodonales chaqueños que ilustran a los distintos colectivos étnicos del Chaco como sujetos atentos y amables en sus vínculos, dando lugar a experiencias que se oponen por momentos a los imaginarios hegemónicos de salvajismo y permiten la emergencia de visiones 
humanizadas de lo indígena. Otras interacciones que han reforzado esta perspectiva de paridad respecto a esos presuntos otros fueron diferentes encuentros entre pueblos originarios a los que los "cumpas" del Vía Campesina asistieron en los últimos años en calidad de miembros del MCNI.

Sin embargo, este imaginario hegemónico del indio salvaje es apropiado nuevamente para reforzar el contraste que implica ser "descendientes de". En este sentido, la discontinuidad generalmente se traza a partir de la referencia al hecho de que, si bien ellos tenían antepasados inmediatos -o conocidos por ellos-que podían ser marcados como "indios", "paisanos" o" matacos", se encuentra la idea de que estos "ya se habían civilizado" respecto a los indígenas en estado puro y salvajes que serían sus antepasados remotos.

Donde civilizarse es entendido, por la negativa, como "no hacer barbaridades" o no comportarse como un animal "bagual", y devenir, por oposición, en seres "civilizados". Esta no-barbarie se encuentra, a su vez, en relación al hecho de tener un trabajo o ser trabajadores, a pesar de encontrarse en condiciones laborales con altísimos niveles de explotación. Además, el indio-ya-civilizado se encuentra asociado, muchas veces, a la figura de agregados: actores que aparecen en los recuerdos trabajando en "puestos" ganaderos, estancias u obrajes muchas veces sin retribución monetaria, circulando cuasi desnudos y descalzos, y bebiendo de las mismas aguadas que los animales. En este sentido, el "indio" no como un ser salvaje, sino como un antepasado explotado, vejado y humillado mediante procesos que lo incorporan en calidad de fuerza de trabajo en procesos cruentos signados por la violencia postfronteriza de las primeras décadas del siglo XX. Figuras históricamente evadidas en la construcción de linajes, que, no obstante, como señala Segato (2010), están siendo retomadas en la actual formación de genealogías.

\section{Conclusión}

Desde la década del setenta, el eje principal de discusión en las ciencias sociales fue la tensión entre agencia y estructura en orden a comprender y explicar las prácticas desde un punto de vista relacional y procesual (Achilli, 2005; Briones, 2008). Como sostiene Briones (2008), resulta fundamental recuperar esta tensión para entender cómo se desarrollan las prácticas de clasificación, adscripción y desadscripción identitaria y evitar visiones constructivistas sumamente contingentes que pierden de vista las relaciones entre discursos identitarios subalternos y procesos de hegemonía. En esta línea, el artículo argumentó que las características asumidas por los procesos de reemergencia étnica de los grupos lule-vilela deben ser entendidas en relación a múltiples factores, estableciendo articulaciones entre experiencias históricas territorialmente localizadas en una región marginal de Santiago del Estero como el Chaco-santiagueño, y transformaciones históricas a nivel global que desbordan ampliamente los contextos situados de la vida cotidiana.

$79 \mathrm{Al}$ analizar las características de los discursos reemergentes, se puso de relieve cómo la referencia a linajes indígenas puede ser comprendida en base a un trabajo colectivo de resignificación de experiencias históricas pasadas a la luz de un presente marcado tanto por conflictos territoriales y procesos organizativos, como por un régimen identitario emergente (Williams, 1997) que permite la demanda de derechos por la diferencia étnica. Sin embargo, también se puso el acento en que las características asumidas por 
estas resignificaciones discursivas dependen de cómo se encuentran estructuradas las relaciones de poder en distintos contextos de la vida cotidiana en los que los actores se presentan como indígenas.

En las situaciones signadas por presencias estatales, domina una definición de las identidades más próximas a la norma de etnicidad obligatoria como requisito para el reconocimiento de aboriginalidad, por lo cual la presentación de los sujetos como lulevilela adquiere mayor notoriedad. En este caso, se hace evidente que los procesos de resignificación se encuentran guiados en parte por un régimen identitario emergente (Williams, 1997) cuyas características fueron instituidas a partir de procesos geopolíticos a escala global que adquirieron formatos particulares en cada país. De este modo, es posible entrever cómo las formaciones identitarias hegemónicas hacen asumir performativamente o exigen roles muchas veces estereotipados a los agentes subalternos, pero también cómo esas asunciones, estatalmente mediadas y apropiadas por las organizaciones sociales, movilizan las subjetividades de quienes atraviesan reemergencias, en tanto y en cuanto los actores devienen lule-vilela y asumen esas identidades como modos contrahegemónicos de restituir un pasado borrado por las élites y resistir en un presente en el que el avance del agro-negocio amenaza con despojarlos de espacios vitales para la reproducción de las familias.

81 Por otro lado, es posible observar un indigenismo de "entrecasa" cuya circulación discursiva se da al interior de las redes de solidaridad establecidas en el marco del movimiento. Esta forma de indigenismo implica la reformulación o incluso el dislocamiento de las identidades criollas impuestas durante el siglo XX, posibilitando concepciones del mestizaje donde predomina la filiación indígena por sobre las presuntas identidades españolas, y el hecho de ser descendientes se constituye en un elemento que da cuenta no solo de un pasado indígena, sino también de un presente y un futuro con existencia legitima.

Esa visión nos remite a plantear la inherente coexistencia entre dos regímenes en tensión al interior de un espacio identitario transformado que impide la existencia de discursos unificados, como los impuestos por distintos dispositivos de poder durante gran parte del siglo XX. En este marco, se puso de relieve cómo, por un lado, es posible observar el predominio de una adscripción más marcadamente étnico-política (Segato, 1998), operativa en contextos públicos investidos de estatalidad. Y, por otro, es posible observar un indigenismo cuya virtud estriba en una relectura de las experiencias de alteridad histórica marcadas por relaciones de racialización y cruentas formas de explotación laboral en los mismos espacios. Esta última construcción, por cierto, da pie a pensar formas de aboriginalidad no necesariamente étnicas como un nuevo horizonte político.

\section{BIBLIOGRAPHY}

Abélés, M. (2012). Antropología de la globalización. Buenos Aires: Ediciones del Sol. 
Abregú, V. (1917). La vida del peón en los obrajes del Chaco santiagueño. Santiago del Estero: Tall. Gráf. de H. Maldonado.

Achilli, E. (2005). Investigar en antropología social. Rosario: Laborde.

Adamovsky, E. (2014). La cuarta función del criollismo y las luchas por la definición del origen y el color del Ethnos argentino (desde las primeras novelas gauchescas hasta c.1940). Boletín del Instituto de Historia Argentina y Americana Dr. Emilio Ravignani, III (41), 50-92.

Adamovsky, E. (2015). El criollismo en las luchas por la definición del origen y el color del ethnos argentino, 1945-1955. Estudios Interdisciplinarios de América Latina y el Caribe, 26(1), 31-63.

Andreani, H. (2018). Búsqueda, regreso y agencia para escritura quichua santiagueña: Mario Tebes (1927-2009). Runa, II (39), 69-89.

Augé, M. (2014). El antropólogo y el mundo global. Buenos Aires: Siglo XXI.

Barbetta, P. (2006). Luchas y sentidos en torno a la problemática de la tierra: El Movimiento Campesino de Santiago del Estero (Tesis de Maestría en Ciencia Política), IDAES (UNSAM), Buenos Aires. Disponible en: http://www.ger-gemsal.org.ar/wp-content/imagenes/tesismaestriabarbetta.pdf

Barbetta, P. (2012). Ecologías de los saberes campesinos: más allá del epistemicidio de la ciencia moderna. Reflexiones a partir del caso del Movimiento Campesino de Santiago del Estero Vía Campesina. Buenos Aires: CLACSO.

Bialet Massé, J. (2010 [1904]). Informe sobre el estado de las clases obreras en Argentina. La Plata: Ministerio de Trabajo de la Provincia de Buenos Aires.

Bilbao, S. (1964). Poblamiento y actividad humana en el extremo norte del Chaco Santiagueño. Cuadernos del Instituto Nacional de Antropología, V, 143-206.

Bonetti, C. (2016). Memorias y alteridades indias. Discursos y marcas indígenas en zonas rurales de Santiago del Estero. San Miguel de Tucumán: Departamento de Publicaciones de la Facultad de Filosofía y Letras de la Universidad Nacional de Tucumán.

Bourdieu, P. (2014). Sobre el Estado. Cursos en el College de France (1989-1992). Barcelona: Anagrama.

Briones, C. (1994). Con la tradición de todas las generaciones pasadas gravitando sobre la mente de los vivos: Usos del pasado e invención de la tradición. Runa, I (21), 99-129.

Briones, C. (1998). La alteridad del "cuarto mundo". Buenos Aires: Ediciones del Sol.

Briones, C. (2004). Construcciones de aboriginalidad en Argentina. Bulletin de la Societe Suisse des Americanistes, 68, 73-90.

Briones, C. (2005). Cartografías argentinas. Políticas indigenistas y formaciones provinciales de alteridad. La Plata: Antropofagia.

Briones, C. (2007). Teorías performativas de la identidad y performatividad de las teorías. Tabula Rasa,6, 55-83.

Brubaker, R. y Cooper, F. (2001). Más allá de 'Identidad'. Apuntes de investigación del CECYP, 7, 30-67.

Butler, J. (2015). Cuerpos que importan. Bs. As: Paidós.

Canals Frau, S. (1953). Poblaciones indígenas de la Argentina, su origen, su pasado, su presente. Buenos Aires: Sudamericana. 
Castelnuovo, N., Castilla, M., Valverde, S. (2019). Movilización, derecho indígena, y antropología en colaboración. QueHaceres, 4, 33-47.

Chamosa, O. (2012). Breve historia del folklore argentino (1920-1970). Identidad, política y nación. Buenos Aires: Edhasa.

Cloud, L., Gonzáles, V. y Lacroix, L. (2019). Categorías, denominaciones y derechos vinculados al indigenismo en América Latina. Variaciones históricas y desafíos actuales. En I. Bellier, (Comp.), Pueblos indígenas en el mundo. El reconocimiento jurídico y político. Buenos Aires: Eudeba.

Corrigan, P. y Sayer, D. (2007). El gran arco. La formación del Estado inglés como revolución cultural, En Lagos y Calla (Comps.), Antropologías del Estado. Dominación y prácticas contestatarias en América Latina. La Paz: PNUD.

Desalvo, A. (2014). El Mocase: orígenes, consolidación y fractura del movimiento campesino de Santiago del Estero. Revista Astrolabio, 12, 271-300.

Di Lullo, O. (1964). Un cuadro de la prehistoria santiagueña. Santiago del Estero: Talleres Gráficos Amoroso S. A.

De Moussy, M. (1864). Description Géographique et Statisque de la Confédérátion Argentine. Paris: Libraire de Firmin Didot Frère.

Domínguez, D. (2009). La lucha por la tierra en Argentina en los albores del Siglo XXI. La recreación del campesinado y de los pueblos originarios (Tesis de Doctorado), Facultad de Ciencias Sociales (UBA), Buenos Aires, Argentina. Disponible en: http://www.ger-gemsal.org.ar/wpcontent/imagenes/ Version-unificada-Tesis-Tierra-y-Campesinado-PDF.doc.pdf

Farberman, J. (2019). De "naciones" a "indios" y de "indios" a "paisanos". Sujetos y prácticas indígenas en Santiago del Estero, siglos XVI a XIX. En D. Escolar y L. Rodríguez (Comps.), Más allá de la extinción. Identidades indígenas en la Argentina criolla siglos XVIII-XX, (pp. 40-85). Buenos Aires: Paradigma Indicial.

Farberman, J. (2010). Tres miradas sobre paisaje, identidad y cultura folklórica en Santiago del Estero. Prismas, I (14), 71-93.

Fazio, L. (1889). Memoria descriptiva de la provincia de Santiago del Estero. Buenos Aires, Compañía Sudamericana de Billetes de Banco.

Figurelli, F. (2016). Alimentación, vida y naturaleza: La construcción de lo campesino entre movimientos populares agrarios. Mundo Agrario, XVII (36), 1-18.

Friedman, J. (2001). Identidad cultural y proceso global. Avellaneda: Amorrortu.

Furlong, G. (1939). Entre los vilelas de Salta. Buenos Aires: Academia literaria de La Plata Jacques, A. (1857). Excursion au Rio-Salado et dans le Chaco. Paris: Imprimerie de Pillet Fils Ainé. Gallo Schaefer, C. (1911). Alma Quichua. Santiago del Estero: S.d.

Gancedo, A. (1885). Memoria descriptiva de Santiago del Estero. Buenos Aires: De Stiller y Laass. Gil Rojas, A. (1954). El Ckaparilo. Santiago del Estero: S.d.

Gil Rojas, A. (1962). Los tipos de mi fogón. Santiago del Estero: S.d.

Goffman, I. (2019). La presentación de la persona en la vida cotidiana. Buenos Aires: Amorrotu.

Gordillo, G. (2006). El Gran Chaco. Buenos Aires: Prometeo.

Gordillo, G. (2010). Lugares del diablo. Buenos Aires: Prometeo. 
Gordillo, G. (2018). Los escombros del progreso. Buenos Aires: Siglo XXI.

Gordillo, G y Hirsch, S. (2010). La presencia ausente: invisibilizaciones, políticas estatales y emergencias indígenas en la Argentina. En G. Gordillo y S. Hirsch (Comps.), Movilizaciones indígenas e identidades en disputa en Argentina (pp. 15-38). Buenos Aires: La Crujía.

Grosso, J. L. (2008). Indios muertos, negros invisibles. Identidad, hegemonía y añoranza. Córdoba: Encuentro.

González Trilla, C. (1921). El Chaqueño: apuntes sobre el Chaco Santiagueño. Santiago del Estero: S.d.

Hall, S. (1992). The Question of Cultural Identity, En S. Hall, D. Held y T. McGrew (Eds.), Modernity and Its Futures. Cambridge: Polity Press.

Hall, S. (2003). Introducción: ¿quién necesita 'identidad'? En S. Hall y P. Du Gay (Comps.). Cuestiones de identidad cultural. Buenos Aires: Amorrortu.

Huret, J. (1986 [1911]). De Buenos Aires al Gran Chaco. Madrid: Hyspanoamérica.

Mansilla, S. (2013). Monte Quemado, su historia y su gente. Monte Quemado, Santiago del Estero: S.d.

Lenton, D. (2014). De centauros a protegidos. La construcción del sujeto de la política indigenista argentina desde los debates parlamentarios (1880 - 1970). Corpus, II (4).

Martínez, A., Taboada, C. y Auat, A. (2011). Los hermanos Wagner, entre ciencia, mito y poesía. Arqueología, campo arqueológico nacional y construcción de identidad en Santiago del Estero, 1920-40. Bernal: Editorial de Universidad Nacional de Quilmes.

Moreno Saravia, M. (1938). Escuela y Patriotismo. En trozos literarios de labor dispersa. Santiago del Estero: Edición de autor.

López, A. L. (1950 [1938]). Narraciones y leyendas supersticiosas y misterios que encierra El Desierto Saladino, Primera parte. Buenos Aires: Librería Perlado.

Memoria presentada por el Ministro de Estado en el Departamento de Guerra y Marina al Congreso Nacional de 1871 (1872). Buenos Aires: Imprenta Americana.

Memoria del Ministerio de Guerra y Marina de la República Argentina presentada al Congreso Nacional en 1873 (1874). Buenos Aires: Imprenta Americana.

Memoria del Ministerio de Guerra y Marina de la República Argentina presentada al Congreso Nacional en 1878. (1879). Buenos Aires: Imprenta Americana.

Memoria de los orígenes de la central campesina de Productores del Norte del MOCASE-VIA CAMPESINA (2016). Buenos Aires: Editorial de la Universidad Nacional de Lujan.

Memoria de los orígenes de la central Campesina de Quimilí del MOCASE-VIA CAMPESINA. (2010). Buenos Aires: Editorial de la Universidad Nacional de Lujan.

Mulhall, M. G. y Mulhall, E. T. (1876). Manual de las repúblicas del Plata. Buenos Aires: Standard.

Lazzari, A. (2017). ¿Por qué el término reemergencia indígena?: Acentuando dis-continuidades y re-emergencias. Conversaciones del Cono Sur, III (1), 43-50.

Lobato y James (inédito). Los santiagueños de Berisso, migración interna, identidad y cultura, Berisso obrero: Memoria, Política y Cultura.

Pankonin, L. (2016). Practicar la memoria, descolonizar el territorio. El caso de la comunidad Lule-vilela, El Retiro-MOCASE-VC (Tesis de Licenciatura en Antropología). Buenos Aires:

Facultad de Filosofía y Letras, UBA. 
Pizarro, C. (2006). Ahora ya somos civilizados. La invisibilidad de la identidad indígena en un área rural del Valle de Catamarca. Córdoba: Editorial de la Universidad Católica de Córdoba.

Prieto, A. (2006). El discurso criollista en la formación de la Argentina moderna. Buenos Aires: Siglo Veintiuno.

Primer Censo de la República Argentina de 1869. (1872). Buenos Aires: Instituto Geográfico Argentino, Imprenta del Porvenir.

Quiroz, J. (2011). El porqué de los que van. Buenos Aires: Editorial Antropofagia.

Rockwell, E. (2009). La experiencia etnográfica. Buenos Aires: Paidós.

Rodríguez, E. (2017). Reemergencia indígena en los países del Plata: Los casos de Uruguay y de Argentina. Conversaciones del Cono Sur, III (1), 1-7.

Rodríguez, E. (2017). Excepcionalidad uruguaya y reemergencia charrúa. Conversaciones del Cono Sur, III(1), 28-36.

Rojas, R. (1907). El país de la Selva. Buenos Aires: Kraft.

Rossi, C. (2004). Espacios y relaciones de poder. Su articulación en Santiago del Estero durante el proceso inicial de implante de la modernidad 1851 - 1875 (Tesis de Doctorado). La Plata: Facultad de Humanidades y Ciencias de la Educación de la Universidad Nacional de La Plata. Disponible en: http://www.memoria.fahce.unlp.edu.ar/tesis/te.181/te.181.pdf

Segato, R. (1998). Identidades políticas/Alteridades históricas: una crítica a las certezas del pluralismo global. Serie Antropología, 34, 32-54.

Segato, R. (2010). Los cauces profundos de la raza latinoamericana: una relectura del mestizaje. Revista Critica y Emancipación-CLACSO. Año II, no 3.

Segato, R. (2015). Critica de la colonialidad en ocho ensayos. Buenos Aires: Prometeo.

Segundo Censo de la República Argentina de 1895. (1898). Buenos Aires: Taller Tipográfico de la Penitenciaría Nacional.

Tasso, A. (1988). Aventura, trabajo y poder. Sirios y libaneses en Santiago del Estero. Buenos Aires: Índice.

Tasso, A. (2007). Ferrocarril, quebracho y alfalfa. Un ciclo de agricultura capitalista en Santiago del Estero, 1870-1940. Córdoba: Alción.

Teruel, A. (2005). Misiones, economía y sociedad. Buenos Aires: Universidad Nacional de Quilmes Editorial.

Trinchero, H. (2000). Los dominios del demonio. Civilización y barbarie en las fronteras de la Nación. Buenos Aires: Eudeba.

Victorica, B. (1885). Campaña del Chaco. Buenos Aires: Imprenta Europa.

Vitar, B. (1997). Guerra y misiones en la frontera chaqueña del Tucumán (1700-1767). Madrid: Consejo Superior de Investigaciones Científicas.

Williams, R. (1997). Marxismo y Literatura. Barcelona: Península.

\section{NOTES}

1. Bilbao (1964) identifica a los departamentos Copo y Alberdi como el extremo norte del Chaco santiagueño. 
2. Maestro oriundo del Departamento Copo.

3. Según Briones (2005, p. 24), a riesgo de perder una masa crítica de subalternos a hegemonizar.

4. En el ámbito de los parajes montaraces de los departamentos Copo y Alberdi, "principales" es

el modo en el cual se denomina a las familias de una determinada zona con mayor estatus económico. Generalmente esta diferencia tiene su razón de ser en que los "principales" tienen como actividad destacada la cría de ganado bovino.

5. Como fue señalado por Briones (2005, p. 27), en EE. UU. una gota de sangre negra o india llevó a sus portadores a identificarse con el antecesor más subvalorado. En Argentina, por el contrario, las estrategias de blanqueamiento fueron posibles, y en muchos casos compulsivas, para indígenas y afrodescendientes generando la posibilidad de "lavar" pertenencias y elegir como punto de identificación al abuelo menos estigmatizado.

6. La categoría "turco" es usada por "criollos" para referir a descendientes de sirios y libaneses, quienes reniegan de dicho uso por considerarlo despectivo.

7. Un dato interesante es que, desde que esta región devino espacio fronterizo, quienes asumían el rol de defensa en los fortines fueron en gran parte grupos indígenas reducidos. Posteriormente, los milicianos ocupados en estas funciones durante el siglo XIX eran descriptos por los viajeros de la época como similares a los indígenas chaqueños en múltiples aspectos (Vitar, 1997; Rossi, 2004; Farberman 2019).

8. Ver la Memorias del Ministerio de Guerra y Marina 1871, 1874, 1879, así como la descripción ofrecida por Benjamín Victorica (1885).

9. Como señala Grosso (2008, p. 21), "indio" se convirtió en el enemigo aglutinador que posibilitaría salvar todo conflicto interno en la construcción de un Estado federativo.

10. Estos números refieren a la cantidad de individuos que utilizaron estas palabras para referir a sus antepasados, sin embargo, la misma idea estaba presente en al menos 15 interlocutores más.

11. Tales fallas se encuentran, por ejemplo, en diferentes fragmentos producidos por viajeros, exploradores, literatos y agentes estatales, entre fines del siglo XIX y las primeras décadas del XX. Se trata de una serie de producciones escritas donde la impronta retorna (Lazzari, 2017) de modos más o menos explícitos, insistentes o matizados, dando cuenta de que la aboriginalidad no se encuentra abolida a pesar de la extinción propiciada por las estadísticas censales desde 1895 en adelante (Jaques, 1856; De Moussy, 1864; Mulhall y Mulhall, 1876; Fazio, 1889; Lascano, 1889; González Trilla, 1921; Moreno Saravia, 1938).

12. Hacemos referencia al artículo 75, inciso 17 de la Constitución Nacional de 1994. Posteriormente se sumó la aprobación en 1992 por parte del Congreso Nacional del convenio 169 de la Organización Internacional del Trabajo plasmada en la ley 24. 071.

13. Respecto a esto último, Desalvo (2014) menciona que entre los objetivos fundacionales del MOCASE destacan algunas reivindicaciones típicamente obreras como obra social, jubilación y salario familiar.

14. Figurelli (2013) caracteriza a la Vía Campesina como un movimiento campesino internacional que surge formalmente en 1993, a partir de la articulación en la cual se entrelazan un número aproximado de ciento cincuenta organizaciones y movimientos de América, Asia y Europa. Se organiza en nueve regiones: América del Sur, América Central, Cuba, el Caribe, América del Norte, Este y Sudeste Asiático, Asia Meridional, África 1 y 2 y Europa. Cada una de ellas se encuentra conformada por un número de organizaciones y movimientos miembros y por una Secretaría Regional. Además, cuenta con una Secretaría Internacional itinerante, que rota a partir de las decisiones tomadas en las Conferencias Internacionales. La Secretaría Regional de América del Sur fue conformada en el 2006 y desde entonces se encuentra en Brasilia. Sus principales consignas fueron la Campaña Global por la Reforma Agraria, contra la violencia hacia las mujeres, y las semillas: patrimonio de los pueblos al servicio de la humanidad. En América del Sur, además, se viene impulsando una campaña contra los agrotóxicos y la soberanía alimentaria de los pueblos campesinos e indígenas. 
15. En parte, la invisibilización étnica es posible porque parte de los archivos de las dos primeras décadas del siglo XIX se perdieron.

16. A principios del siglo $X X$, un inspector escolar oriundo de la región señalaba el predominio de la filiación indígena entre los "criollos" de la zona (Moreno Saravia, 1938). Y, de modo similar, historiadores y antropólogos contemporáneos (Teruel, 2005; Gordillo, 2018) apoyaron dicha hipótesis, tanto para Salta como para el caso santiagueño.

17. Hablamos de los "mocaseros" reconocidos como lule-vilela.

18. En la perspectiva de los actores con los que trabajé, esta categoría hace referencia a antepasados que provienen de las orillas del río Salado. Los "shalacos" o "paisanos saladinos" (Gancedo, 1885) constituían grupos estigmatizados en la provincia, tanto por las personas del mundo rural como urbano. En la actualidad, "shalaco" es usado despectivamente en diversos espacios como sinónimo de incivilizado y, a veces, de "indio". Sin embargo, algunas otras poblaciones construyeron identidad social con dicha etiqueta en zonas quichua hablantes del departamento Figueroa (Andreani, 2018).

19. Antes de la formación de las organizaciones de base como el MOCASE, la categoría "campesino" era utilizada como contraste con la de "pueblero", para distinguir entre "criollos" de poblados urbanos o semiurbanos y habitantes de monte adentro. Y las personas de los parajes campesinos solían percibirla como una etiqueta despectiva.

20. Algunos de estos diálogos ( 5 de 8 ) no sucedieron en los departamentos Alberdi y Copo, sino en los vecinos departamentos de Moreno y Figueroa, por lo cual no se encuentran consignados en el apartado metodológico.

\section{ABSTRACTS}

This article is based on an ethnographic work carried out between 2014 and 2019. It reflects on the characteristics assumed by the discourses of aboriginality between members of the Peasant Movement of Santiago del Estero-Via Campesina (MOCASE-VC) ascribed to the Lule-Vilela ethnic identity, in the Copo and Alberdi departments of the Argentine province of Santiago del Estero. The objective is to track, describe and analyze mobilized signifiers in order to present themselves in different contexts of daily life, as members of said indigenous ethnic group, and the relationship of these identity practices with hegemonic processes that model them, such as national/provincial formations of alterity and the current processes of fragmentation of the identity space on a global scale. The sustained argument claims that discursive constructions highlight a productive oscillation between two forms assumed by said identity. On the one hand, it is possible to observe the predominance of a more accentuated ethnic-political ascription, whose emergence takes shape in contexts of political-legal demand to state institutions. On the other, it is possible to observe a budding indigenism as an alternative form of politics of alterity, whose discursive circulation acquires a greater presence within the networks of the movement. In the context of this indigenous opening of local Creole identities, nodal signifiers such as peasant-indigenous, descendant, and race / blood are analyzed.

El presente artículo se basa en un trabajo etnográfico realizado entre 2014 y 2019. Reflexiona en torno a las características asumidas por los discursos de aboriginalidad entre miembros del Movimiento Campesino de Santiago del Estero-Vía Campesina (MOCASE-VC) adscriptos a la identidad étnica lule-vilela, en los departamentos Copo y Alberdi de la provincia argentina de 
Santiago del Estero. El objetivo consiste en rastrear, describir y analizar significantes movilizados en orden a la presentación en diferentes contextos de la vida cotidiana como miembros de dicha etnia indígena y la relación de estas prácticas identitarias con procesos hegemónicos que contribuyeron a modelarlos, como son las formaciones nacionales/provinciales de alteridad y los actuales procesos de fragmentación del espacio identitario a escala global. El argumento sostenido plantea que las construcciones discursivas ponen de relieve una oscilación productiva entre dos formas asumidas por dicha identidad. Por un lado, es posible observar el predominio de una adscripción más marcadamente étnico-política, cuya emergencia adquiere forma en contextos de demanda político-jurídica a instituciones estatales. Por otro, es posible observar un indigenismo en ciernes como una forma alternativa de política de la alteridad, cuya circulación discursiva adquiere mayor presencia al interior de las redes del movimiento. En el marco de esta apertura indigenista de las identidades criollas, se analizan significantes nodales como campesino-indígena, descendiente, y raza/sangre.

\section{INDEX}

Keywords: Aboriginality, ethnic identity, Lule-Vilela, peasant-indigenous, social movements.

Palabras claves: Aboriginalidad, identidad étnica, lule-vilela, campesino-indígena, movimientos sociales.

\section{AUTHOR}

\section{PABLO CONCHA MERLO}

Consejo Nacional de Investigaciones Científicas Técnicas

y Universidad Nacional de Santiago del Estero

Argentina

Correo electrónico: pacm85@hotmail.com 